\title{
Seçilmiş Entegrasyon Örgütlerinde Satın Alma Gücü Paritesi Teorisinin Geçerliliğinin Fourier Fonksiyonu Kullanarak Fraksiyonel Birim Kökleriyle Test Edilmesi
}

Havanur ERG ÜN-TATAR (https://orcid.org/0000-0002-4284-9083), Department of Economics, Bartın University, Turkey; e-mail: havanurergun@bartin.edu.tr

\section{Testing the Validity of The Purchasing Power Parity Theory in Selected Integration Organizations by Using the Fourier Function with Fractional Unit Roots}

\begin{abstract}
The specific terminology of purchasing power parity has been at the centre of international policy debates among the major industrialized countries in the years after World War I. In this study, fractional unit root analysis has been conducted by using Fourier functions. The purchasing power parity theory has been assessed among different integration organizations such as NAFTA, MERCOSUR, EU15, and selected OECD countries for the 1960-2019 period. Fractional Frequency Fourier ADF and conventional ADF tests were performed in the study. Traditional ADF results have been calculated for countries where trigonometric terms are meaningless. According to the analysis results, it has been determined that the purchasing power parity theory is valid for integration organizations except for MERCOSUR.
\end{abstract}

Keywords : : Purchasing Power Parity, Real Exchange Rate, Unit Root Test.

JEL Classification Codes : F10, F41, C2.

Öz

Satın alma gücü paritesinin özel terminolojisi, I. Dünya Savaşı'ndan sonraki yıllarda, başlıca sanayileşmiş ülkeler arasında, uluslararası politika tartışmalarının merkezine oturmuştur. Bu çalışmada, Fourier fonksiyonları kullanılarak, fraksiyonel birim kök incelemesi yapılmıştır. Teorem 1960-2019 dönemi için NAFTA, MERCOSUR, AB15 ve seçilmiş OECD ülkeleri gibi farklı entegrasyon örgütleri kapsamında ele alınmıştır. Çalışmada, Kesirli Frekanslı Fourier ADF ve geleneksel ADF testleri yapılmıştır. Trigonometrik terimleri anlamsız olan ülkelerde geleneksel ADF sonuçları hesaplanmıştır. Analiz sonuçlarına göre, MERCOSUR hariç diğer entegrasyon şekillerinde satın alma gücü paritesi hipotezinin geçerli olduğu tespit edilmiştir.

Anahtar Sözcükler $\quad$ ： Satın Alma Gücü Paritesi, Reel Döviz Kuru, Birim Kök Testi. 


\section{Giriş}

Satın alma gücü paritesi hem teorik hem de pratik ekonomik analizde varsayılmış bir denge koşuludur. Satın alma gücü paritesi teorisi, döviz kuru, yurt içi fiyat seviyesi ve yabancı fiyat seviyesini ilişkilendiren ve en eski döviz kuru teorilerinden biri olmakla birlikte; aynı zamanda uluslararası ekonomide döviz kurunun oluşması için çok önemli bir teoridir (Kozul, 2013: 254).

Satın alma gücü paritesi (SGP) teorisi, ülkeler arasındaki fiyatlardaki değişimin döviz kurları ile eşleşeceğini varsayar; yani nominal döviz kurları, ekonomiler arasındaki enflasyon oranlarındaki farklılıkları yansıtacaktır. Özellikle mutlak SGP, iki ülke arasındaki uzun vadeli denge döviz kuru, fiyat seviyelerinin oranına eşit olacağını önermektedir. Ancak gerçekte, ticareti yapılmayan mal ve hizmetlerin varlığ ve kusurlu pazarlar gibi döviz kurları ile fiyat seviyeleri arasındaki ilişkiyi zayıflatabilecek faktörler vardır. Ayrıca, tüketim modellerindeki uluslararası farklılıklar, ürün niteliklerindeki farklılıklar ve listelenen ve işlem fiyatları arasındaki farklılıklar, döviz kurları ile fiyat seviyeleri arasındaki bağlantıyı etkileyebilecek bazı engellerdir (Ismail, 2011: 16).

Teoriye dair, literatürde geniş ampirik çalışmalar bulunmasına rağmen, geçerlilikleriyle ilgili temel bir fikirde odaklanılamamıştır. 1973 yılı sonrası verileri incelemek için, Im, Pesaran ve Shin (2002) ve Levin, Lin ve Chu (2002) tarafindan geliştirilen yöntemlerle konuyu ele alan çalışmaların çoğunun sonucu, satın alma gücü hipotezinin geçerliliğini desteklemektedir (Alba \& Papell, 2007: 2).

Uzun dönemli yeni verilerin mevcudiyeti ve yeni ekonometrik tekniklerin geliştirilmesi, SGP ile ilgili ampirik literatürün yeniden doğmasına sebep olmuştur. Kısa vadede zaman serisi teknikleri, uzun vadede geçerliliği test etmek için, reel döviz kuru (RER) üzerinde birim kök ve eşbütünleşme analizleri kullanılmıştır (Calderón \& Duncan, 2003: 1).

Satın alma gücü paritesinin geçerliliğine yönelik, literatürde oldukça fazla çalışma bulunmaktadır. Ancak literatürdeki çalışmaların büyük bölümü sınırlı ülke ve veriyle teoriyi test etmektedir. Oysa bu çalışmada, veri olarak dört farklı entegrasyon şekli, geniş zaman aralığında incelenmiştir. Satın alma hipotezinin geçerliliği, Fourier fonksiyonları kullanarak fraksiyonel birim kök testiyle analiz edilmiştir. Literatürde Fourier yaklaşımı (Fourier ADF, Fourier KSS, Fourier KPSS ve Fourier Shin gibi) kullanan çalışmalar olsa bile, söz konusu çalışmalarda izin verilen frekans değeri tam sayılar olmaktadır. Ancak bu çalışmada kullanılan yöntemde, frekans değerinin kesirli olmasına izin verilmektedir. Bu yöntem sayesinde, geçici şokların bile kalıcı etkileri tespit edilebilmektedir. Bu durum, uygun politikanın tespit edilmesinde ve uygulanmasında doğru bilgi sunmaktadır. Çalışmada, bu yöntemin kullanılmasının en önemli nedeni, yapısal kırılmaları anlık kırılmalar yerine düzgün kırılmalar olarak modellemeye izin vermesidir. SGP'nin bu açıdan literatürdeki çalışmalara kıyasla farklı bir yöntemle ve çeşitli entegrasyon ülke gruplarıyla ele alınması, 
güncel literatüre önemli katkı sunmaktadır. Analizler için, 1960-2019 dönemi yıllık veriler kullanılarak reel döviz kuru verileri NAFTA, MERCOSUR, AB15 ve seçilmiş OECD ülkeleri gibi farklı entegrasyon örgütleri kapsamında incelenmiştir.

Çalışmada öncelikle, konunun teorik altyapısına ilişkin kavramsal çerçeveye dair bilgi verilmiştir. Daha sonra, konuya dair yapılımış çalışmalara yer verilmiştir. Çalışmanın son bölümünde ise, veri seti ve kullanılacak yöntem ile ilgili bilgilendirme yapıldıktan sonra, analiz sonuçlarına geçilmiştir. Çalışmada kesirli frekanslı Fourier birim kök ve geleneksel birim kök incelemeleri yapılmıştır. Analiz sonuçları incelendikten sonra, çalışma sonuç bölümüyle tamamlanmıştır.

\section{Reel Döviz Kuruna İlişkin Teorik Çerçeve}

SGP hipotezi, uluslararası ekonomi alanında eski bir hipotez olarak kabul edilmektedir. İlk olarak, İsveçli iktisatçı Gustan Cassel tarafından 1918'de tanıtılmıştır. Bu yöntemi, I. Dünya Savaşı'nın sonunda ülkelerin resmi döviz kurlarını belirlemek için, bir temel olarak önermiştir. Daha sonra, SGP hipotezi, merkez bankaları ve politika yapıcılar tarafından bir para biriminin denge değerinden saptığında, bir gösterge olarak yaygın bir şekilde kullanılmıştır (Merza, 2017: 188).

Satın Alma Gücü Paritesinin temel yapı taşı 'Tek Fiyat Yasası'dır. Tek fiyat yasası, nakliye maliyetleri ve tarifeler gibi ticaret engellerinin yokluğunda, fiyatlar aynı para biriminde ifade edildiğinde, ülkeler arasında aynı ve ticareti yapılan bir malın fiyatının eşitleyeceğini ortaya koymaktadır (Nusair, 2003: 132).

Aynı mallar, aynı ağırlıkta toplam fiyat seviyesini oluşturmak için kullanılan her bir ülkenin pazar sepetine girerse, tek fiyat yasası ilgili ülkeler arasında SGP'nin geçerli olması gerektiği anlamına gelmektedir. Seviye fiyatları, uzun vadede piyasa döviz kurları üzerinden aynı para birimine dönüştürüldüğünde, ekonomik olarak bütünleşmiş ülkeler arasında neden farklı olması gerektiğine dair hiçbir kanıt bulunmamaktadır. Nitekim, bir malın ticareti yapılabildiğinde, fiyatı ülkeler arasında tek fiyat yasası gereğince eşitlenmelidir. Bununla birlikte, fiyat farklılıklarının yapısal olması halinde, sabit kalmaları veya yavaş gelişmeleri beklenmektedir (Voinea, 2013: 6).

SGP hipotezi, farklı ülkelerdeki aynı mal ve hizmetlerin maliyetinin, uzun vadede eşit olma eğiliminde olduğunu ifade etmektedir. Bu hipotez, mutlak biçimde ve göreli biçimde ifade edilebilir. SGP hipotezinin mutlak biçimi, döviz kurunun iki ülke arasındaki göreli fiyatların, eşit olmasına yol açacağını göstermektedir. Söz konusu denklem şu şekildedir (Akçay \& Erataş, 2015: 83):

$$
p_{t}=\frac{p_{t}^{*}}{e_{t}}
$$


Yukarıda (1) nolu denklemde, $e_{t}$ t zamanındaki döviz kurunu temsil etmektedir. Diğer bir deyişle, bir yabancı para birimi satın almak için gereken yerel para birimi sayısı. $\mathrm{Pt}$, t zamanındaki yerel fiyat seviyesi ve $\mathrm{Pt} * \mathrm{t}$ zamanındaki yabancı fiyat seviyesidir.

Göreli satın alma gücü paritesine göre, nominal döviz kurunun değişim oranı, yerli ve yabancı endeks fiyatlarının değişim oranları arasındaki farka eşittir. Dolayısıyla, göreceli satın alma gücü paritesi teorisi, belirli bir dönemdeki nominal döviz kurunun değişim oranının, aynı dönemde gözlemlenen ülkelerdeki enflasyon oranlarının farkına eşit olması durumunda geçerlidir (Kozul, 2013: 255).

SGP teoreminin geçerliliğine yönelik çalışmalar, literatürde geniş yer tutmakla birlikte, sonuçları açısından farklıklar bulunmaktadır. Çalışmaların çoğu, Bretton-Woods sisteminin terk edilmesinden bu yana, genellikle SGP'den önemli sapmaların olduğunu tespit etmiş̧ir. İlişkiyi kısa vadeli inceleyen çalışmaların birçoğu, fiyat seviyelerindeki çok büyük değişikliklerin yaşandığı süre boyunca bile, kısa vadede teoremin önemli bir geçerliliğe sahip olabileceğini ortaya koymuştur (Rogoff, 1996).

SGP teoreminin geçerliliği, bazı faktörlerden dolayı kalıcı olmamaktadır. Söz konusu belirleyicilerden en önemlisi, ticarete konu olan ve olmayan mallar arasındaki göreli dengeyi değiştiren verimlilik farklarıdır. Balassa-Samuelson etkisi olarak adlandırılan bu hipotez hakkında, literatürde geniş çalışma bulunmaktadır. Örneğin Rogoff (1996) çalışmasında, Balassa-Samuelson etkisinin orta vadede ilişkili olabileceğini, ancak bilginin yayılmasıyla birlikte fiziksel ve beşerî sermayenin hareketliliğinin, çok uzun vadede mutlak SGP'ye doğru bir eğilim oluşturduğunu ortaya koymuştur (Widodo, 2015: 10).

Satın alma gücü paritesi, başlıca sanayileşmiş ülkeler arasındaki ikili döviz kurlarına uygulandığı zaman, uzun vadede geçerli uluslararası paritedir. Gelişmekte olan ülkeler için veri kullanılabilirliği sorunları, çoğu çalışmaya dair kanıtların daha az kesin olmasına neden olmaktadir (Dal Bianco, 2008: 37).

\section{Literatür}

Yerli ve yabancı literatür açısından satın alma gücü paritesinin geçerliliği, üzerinde çok durulan konulardan birisidir. Literatürde yapılan çalışmalara bakıldığında, büyük çoğunluğunun tek bir ülkeyi veya bir ülke grubunu ele aldığg görülmektedir. Ancak bu çalışma, farklı entegrasyon gurupları açısından, geniş zaman aralığı ve güncel yaklaşımla konuyu ele alması açısından literatüre önemli katkı sunması beklenmektedir. Ayrıca literatürde kullanılan Fourier yaklaşımlardan farklı olarak bu çalışmada yer alan analizlerde frekans değerinin kesirli olarak değişmesine izin verilmiş̧ir. Böylelikle değişimlerin veya şokların etkilerinin geçici mi yoksa kalıcı mı olduğunu analiz etmeye olanak tanınmıştır. Bu nedenle de literatüre önemli katkı sağlanacağı tahmin edilmektedir. Literatürde yer alan çalışmaların bazıları şu şekildedir: 
Ergün-Tatar, H. (2021), "Seçilmiş Entegrasyon Örgütlerinde Satın Alma Gücü Paritesi Teorisinin Geçerliliğinin Fourier Fonksiyonu Kullanarak Fraksiyonel Birim Kökleriyle Test Edilmesi”, Sosyoekonomi, 29(49), 373-388.

Tablo: 1

Satın Alma Gücü Paritesi Teorisinin Geçerliliğini Test Eden Seçili Çalışmalar

\begin{tabular}{|c|c|c|c|}
\hline Yazar & Veri Dönemi & Kullanılan Yöntem & Elde Edilen Sonuçlar \\
\hline $\begin{array}{c}\text { Lothian \& Taylor } \\
\text { (1996) }\end{array}$ & $\begin{array}{l}1791 \\
1990 \\
\end{array}$ & DF and PP testi & 3 gelişmiş ülke için hipotez geçerlidir. \\
\hline $\begin{array}{l}\text { Papell } \\
(1997) \\
\end{array}$ & $\begin{array}{l}1973: 1 \\
1994: 9\end{array}$ & ADF birim kök testi & 20 gelişmiş ülke için hipotez geçerlidir. \\
\hline $\begin{array}{c}\text { Culver \& Papell } \\
(1999)\end{array}$ & $\begin{array}{l}1973: 1 \\
1996: 4\end{array}$ & $\begin{array}{l}\text { ADF, KPSS, Shin (1994) } \\
\text { testleri; Cointegration testi }\end{array}$ & 21 gelişmiş ülke için hipotez geçerlidir. \\
\hline $\begin{array}{c}\text { Muscatelli \& Spinelli } \\
\text { (1999) }\end{array}$ & $\begin{array}{l}1861 \\
1998 \\
\end{array}$ & ADF birim kök testi & Seçili örneklem grubunda, SGP geçerli değildir. \\
\hline $\begin{array}{c}\text { Mkenda } \\
(2001) \\
\end{array}$ & $\begin{array}{l}1965 \\
1996 \\
\end{array}$ & ADF birim kök testi & Seçilmiş Afrika ülkelerinde, SGP geçerli değildir. \\
\hline $\begin{array}{c}\text { Zumaquero \& Urrea } \\
(2002)\end{array}$ & $\begin{array}{c}1975: 1 \\
1995: 12\end{array}$ & $\begin{array}{l}\text { Bai-Perron birim kök testi ve } \\
\text { Granger ECM kointegrasyon }\end{array}$ & 7 gelişmiş ülke için, SGP geçerli değildir. \\
\hline $\begin{array}{l}\text { Taylor } \\
(2002)\end{array}$ & $\begin{array}{l}1870 \\
1990\end{array}$ & $\begin{array}{l}\text { Eşbütünleşme yöntemi ve } \\
\text { ADF-GLS testleri. }\end{array}$ & $\begin{array}{l}20 \text { gelişmiş ve gelişmekte olan ülkeler için } \\
\text { SGP geçerli }\end{array}$ \\
\hline $\begin{array}{l}\text { Nusair } \\
(2003)\end{array}$ & $\begin{array}{l}1973: 2 \\
1999: 4\end{array}$ & $\begin{array}{c}\text { ADF, PP ve KPSS } \\
\text { birim kök testleri }\end{array}$ & $\begin{array}{l}\text { Asya ülkelerinin ele alındığı çalışmada, SGP Endonezya, } \\
\text { Kore, Malezya ve Tayland için geçerlidir. }\end{array}$ \\
\hline $\begin{array}{l}\text { Calderón \& Duncan } \\
(2003)\end{array}$ & $\begin{array}{l}1810 \\
2002 \\
\end{array}$ & $\begin{array}{l}\text { ADF, PP, DF-GLS, Ng-Perron, } \\
\text { KPSS birim kök testleri }\end{array}$ & SGP, Şili için geçerlidir. \\
\hline $\begin{array}{l}\text { Freixo \& Barbosa } \\
(2004)\end{array}$ & $\begin{array}{l}1959 \\
2004\end{array}$ & ADF birim kök testi & Brezilya için, SGP geçerli değildir. \\
\hline $\begin{array}{l}\text { Doğanlar } \\
(2006)\end{array}$ & $\begin{array}{l}1995 \\
2002\end{array}$ & $\begin{array}{c}\text { Engle-Granger ve } \\
\text { Phillips Hansen testleri }\end{array}$ & $\begin{array}{l}\text { Azerbaycan, Kırgızistan ve Kırgızistan için } \\
\text { SGP geçerli değildir. }\end{array}$ \\
\hline $\begin{array}{c}\text { Koukouritakis } \\
(2009)\end{array}$ & $\begin{array}{c}1995: 1 \\
2006: 12\end{array}$ & ADF birim kök testi & $\begin{array}{l}\text { Yeni AB ülkelerinin incelendiği çalışmada, Bulgaristan, } \\
\text { Kıbrıs, Romanya ve Slovenya için SGP geçerlidir. }\end{array}$ \\
\hline $\begin{array}{l}\text { Kalyoncu, Kula } \\
\text { \& Aslan (2010) }\end{array}$ & $\begin{array}{l}1970 \\
1998\end{array}$ & LM birim kök testi & SGP, MENA ülkelerinde geçerlidir. \\
\hline $\begin{array}{l}\text { Acaravc1 \& Öztürk } \\
(2010)\end{array}$ & $\begin{array}{l}1992: 1 \\
2009: 1\end{array}$ & ADF ve KPSS birim kök testleri & $\begin{array}{l}\text { SGP, seçilen altı geçiş ekonomi ülkesi için } \\
\text { geçerli değildir. }\end{array}$ \\
\hline $\begin{array}{l}\text { Su, Tsangyao } \\
\& \text { Chang }(2011) \\
\end{array}$ & $\begin{array}{l}1994: 12 \\
2010: 2\end{array}$ & Fourier birim kök testi & $\begin{array}{l}15 \text { Latin Amerika ülkesinde } 4 \text { ülke için } \\
\text { SGP geçerlidir. }\end{array}$ \\
\hline $\begin{array}{l}\text { Wu, Cheng } \\
\text { \& Hou (2011) }\end{array}$ & $\begin{array}{l}1976 \\
2006\end{array}$ & CİPS birim kök testi & SGP, Afrika ve Latin Amerika için geçerlidir. \\
\hline $\begin{array}{c}\text { Chang \& Lee } \\
(2011)\end{array}$ & $\begin{array}{c}1986: 1 \\
2019: 10\end{array}$ & Esnek Fourier Durağanlık Testi & $\begin{array}{l}\text { Doğu Asya ülkelerinde Endonezya ve } \\
\text { Japonya için SGP geçerlidir. }\end{array}$ \\
\hline $\begin{array}{l}\text { Chang, Liu } \\
\& \mathrm{Su}(2012)\end{array}$ & $\begin{array}{c}1993 \\
2008 \\
\text { (aylik) }\end{array}$ & Fourier birim kök testi & 7 Orta ve Doğu Avrupa ülkesinde SGP geçerlidir. \\
\hline $\begin{array}{c}\text { Jiranyakul \& Batavia } \\
(2012)\end{array}$ & $\begin{array}{c}1997: 6 \\
2001: 12\end{array}$ & $\begin{array}{l}\text { ADF, PP, DF-GLS, Ng-Perron, } \\
\text { KPSS birim kök testleri }\end{array}$ & Tayland için, SGP geçerli değildir. \\
\hline $\begin{array}{l}\text { Su, Liu, Zhu } \\
\& \text { Lee (2012) }\end{array}$ & $\begin{array}{c}1997 \\
2009 \\
\text { (aylik) }\end{array}$ & Fourier birim kök testi & 7 OPEC ülkesinde SGP geçerlidir. \\
\hline $\begin{array}{c}\text { Öcal } \\
(2013)\end{array}$ & 1991 & Zirot-Andrews birim kök testi & Romanya için, SGP geçerli değildir. \\
\hline $\begin{array}{l}\text { Korkmaz, Çevik } \\
\text { \& Çevik (2013) }\end{array}$ & $\begin{array}{l}1995: 1 \\
2009: 1\end{array}$ & $\begin{array}{c}\text { ADF, PP, KPSS birim kök testleri } \\
\text { ve eşbütünleşme analizi }\end{array}$ & $\begin{array}{l}\text { Azerbaycan, Kazakistan ve Kırgızistan'da } \\
\text { SGP geçerli değildir. }\end{array}$ \\
\hline $\begin{array}{l}\text { Ağayev } \\
(2013)\end{array}$ & $\begin{array}{c}1995: 1 \\
2012: 12\end{array}$ & ADF birim kök testi & Kazakistan için, SGP geçerlidir. \\
\hline $\begin{array}{c}\text { Y1lancı \& Eriş } \\
(2013)\end{array}$ & $\begin{array}{l}1980: 1 \\
2011: 7\end{array}$ & Fourier birim kök testi & 33 Afrika ülkesinin 22 tanesinde SGP geçerlidir. \\
\hline $\begin{array}{c}\text { He, Chou } \\
\text { \& Chang (2014) }\end{array}$ & $\begin{array}{l}1994: 12 \\
2010: 2\end{array}$ & Panel SURKSS & 15 Latin Amerika ülkesi için SGP geçerli değildir. \\
\hline $\begin{array}{c}\text { Büberkökü } \\
(2014)\end{array}$ & $\begin{array}{c}2003: 1 \\
2012: 12\end{array}$ & $\begin{array}{c}\text { Pedroni, Kao ve Johansen Fisher } \\
\text { koentegrasyon tetsleri }\end{array}$ & 21 yükselen ekonomi için, SGP zayıf formu geçerlidir. \\
\hline $\begin{array}{l}\text { Al-Gasaymeh \& Kasem } \\
(2015)\end{array}$ & $\begin{array}{c}2000: 1 \\
2012: 12\end{array}$ & ADF birim kök testi & $\begin{array}{l}\text { Ürdün ve başlıca ticaret ortakları için } \\
\text { SGP geçerli değildir. }\end{array}$ \\
\hline $\begin{array}{l}\text { Si Mohammed, Chérif Touil } \\
\text { \& Maliki (2015) }\end{array}$ & $\begin{array}{l}2003: 1 \\
2015: 5\end{array}$ & Panel hata düzeltme modeli (PECM) & Cezayir için, SGP geçerlidir. \\
\hline $\begin{array}{c}\text { Akçay \& Erataş } \\
(2015) \\
\end{array}$ & $\begin{array}{l}1995 \\
2012 \\
\end{array}$ & $\begin{array}{c}\text { Birinci ve İkinci nesil } \\
\text { birim kök testleri } \\
\end{array}$ & G7 ülkeleri için, SGP geçerli değildir. \\
\hline $\begin{array}{l}\text { Vasconcelos \& Júnior } \\
(2016)\end{array}$ & $\begin{array}{l}1994 \\
2014\end{array}$ & $\begin{array}{l}\text { Harvey ve ark. (2008) doğrusallık testi } \\
\text { ve doğrusal olmayan birim kök testi }\end{array}$ & $\begin{array}{l}\text { Latin Amerika ülkelerinin ele alındığı çalışmada, } \\
\text { yedi ülkeden yalnızca üçünde SGP geçerlidir. }\end{array}$ \\
\hline $\begin{array}{l}\text { Atasoy } \\
(2016)\end{array}$ & $\begin{array}{l}1996: 05 \\
2013: 12\end{array}$ & ADF birim kök testi & $\begin{array}{l}\text { SGP, Brezilya, Hindistan, Güney Afrika ve Türkiye için } \\
\text { geçerli olmadığı, yalnızca Endonezya için geçerlidir. }\end{array}$ \\
\hline $\begin{array}{l}\text { Destek \& Okumuş } \\
(2016)\end{array}$ & $\begin{array}{l}1990: 1 \\
2015: 5\end{array}$ & Fourier ADF ve Fourier KSS & 27 OECD ülkesinin 14'ünde SGP geçerlidir. \\
\hline
\end{tabular}


Ergün-Tatar, H. (2021), "Seçilmiş Entegrasyon Örgütlerinde Satın Alma Gücü Paritesi Teorisinin Geçerliliğinin Fourier Fonksiyonu Kullanarak Fraksiyonel Birim Kökleriyle Test Edilmesi”, Sosyoekonomi, 29(49), 373-388.

\begin{tabular}{|c|c|c|c|}
\hline $\begin{array}{l}\text { Merza } \\
(2017) \\
\end{array}$ & $\begin{array}{l}2006 \\
2015\end{array}$ & ADF ve PP birim kök testleri & Kuveyt içi SGP geçerli değildir. \\
\hline $\begin{array}{l}\text { Altıner \& Bozkurt } \\
(2018)\end{array}$ & $\begin{array}{l}1994 \\
2017\end{array}$ & SURADF birim kök testi & SGP, E7 ülkeleri için geçerlidir. \\
\hline $\begin{array}{l}\text { Aydin } \\
(2018)\end{array}$ & $\begin{array}{c}1994 \\
2017 \\
\text { (aylik) }\end{array}$ & Fourier birim kök testleri & Kırılgan beşlide sadece Türkiye için SGP geçerlidir. \\
\hline $\begin{array}{l}\text { Songur \& Songur } \\
(2018)\end{array}$ & $\begin{array}{l}1995: 10 \\
2017: 12\end{array}$ & $\begin{array}{l}\text { Fourier KPSS ve } \\
\text { Fourier Shin }\end{array}$ & $\begin{array}{l}10 \text { Avrasya ülkesinin ele alındığı çalışmada, } \\
7 \text { tanesinde SGP geçerlidir. }\end{array}$ \\
\hline $\begin{array}{l}\text { Y1lanc1, Aslan } \\
\text { \& Özgür (2018) }\end{array}$ & $\begin{array}{l}1980 \\
2015\end{array}$ & $\begin{array}{l}\text { Fourier Birim Kök ve } \\
\text { Eşbütünleşme Tesleri }\end{array}$ & $\begin{array}{l}14 \text { ülke için reel döviz kurlarının ortalama geri } \\
\text { dönme eğilimlerinin olmadığı tespit edilmiştir. }\end{array}$ \\
\hline $\begin{array}{l}\text { Çil \& Trraşoğlu } \\
\text { (2018) }\end{array}$ & $\begin{array}{l}1990: 1 \\
2016: 2\end{array}$ & $\begin{array}{c}\text { ADF ve Sims (1988) } \\
\text { Bayesian birim kök testleri }\end{array}$ & $\begin{array}{l}\text { Kırılgan beş ülkenin ele alındığı çalışmada, } \\
\text { SGP sadece Hindistan için geçerlidir. }\end{array}$ \\
\hline $\begin{array}{c}\text { Kaya \& Çelik } \\
(2018)\end{array}$ & $\begin{array}{l}2002: 10 \\
2017: 12\end{array}$ & ARFIMA modeli & Türkiye için, SGP geçerlidir. \\
\hline $\begin{array}{l}\text { Rezazadeh, Mohammadpoor } \\
\text { \& Fattahi (2018) }\end{array}$ & $\begin{array}{l}1960 \\
2017\end{array}$ & ADF birim kök testi & İran için, SGP geçerli değildir. \\
\hline $\begin{array}{c}\text { Ziad \&Abdallah } \\
(2018)\end{array}$ & $\begin{array}{l}1980 \\
2017\end{array}$ & ADF ve PP birim kök testleri & Ürdün için, SGP geçerli değildir. \\
\hline $\begin{array}{l}\text { Bilgin } \\
(2018) \\
\end{array}$ & $\begin{array}{l}1986: 1 \\
2017: 4\end{array}$ & $\begin{array}{c}\text { ADF birim kök testi ve } \\
\text { Johansen eşbütünleşme testi }\end{array}$ & $\begin{array}{l}\text { Türkiye için, mutlak satın alma hipotezinde } \\
\text { dair kanıt bulunamamıştır. }\end{array}$ \\
\hline $\begin{array}{l}\text { Suluk \& Tanriseven } \\
\text { (2018) }\end{array}$ & $\begin{array}{l}2000 \\
2016\end{array}$ & LM testi & Euro kullanan AB ülkelerinde, SGP geçerlidir. \\
\hline $\begin{array}{l}\text { Güriş \& Tiraşoğlu } \\
(2018)\end{array}$ & $\begin{array}{l}1993: 1 \\
2015: 3\end{array}$ & Doğrusal olmayan birim kök testleri & $\begin{array}{l}\text { BRICS ülkelerinin analiz edildiği çalışmada, Rusya, } \\
\text { Hindistan ve Çin için SGP geçerli değildir. }\end{array}$ \\
\hline $\begin{array}{l}\text { Köktürk \& Ural } \\
(2019)\end{array}$ & $\begin{array}{c}2003: 1 \\
2018: 12\end{array}$ & FKPSS birim kök testi & Türkiye için, incelenen dönemde SGP geçerlidir. \\
\hline $\begin{array}{l}\text { Coşkun } \\
(2020)\end{array}$ & $\begin{array}{l}1994: 1 \\
2018: 1\end{array}$ & Doğrusal olmayan birim kök testi & $\begin{array}{l}\text { Kırılgan beşlide Güney Afrika ve } \\
\text { Hindistan için SGP geçerlidir. }\end{array}$ \\
\hline
\end{tabular}

\section{Analiz}

$\mathrm{Bu}$ başlık altında, çalışmada kullanılan veriler ve yöntem hakkında detaylı bilgi verilerek, analiz sonuçlarına yer verilecektir.

\subsection{Veri Seti}

Satın alma gücü paritesi teorisinin geçerliliğini analiz edebilmek için, dört farklı entegrasyon örgütü seçilmiştir. Literatürdeki çalışmalardan farklı olarak, konuyu geniş perspektifte ele almak için, ülke sayısı ve zaman aralığı geniş kapsamlı seçilmiştir. Çünkü literatürdeki çalışmaların çoğunda, konu çoğunlukla tek bir ülke veya ülke grubu özelinde ele alınmıştır. Bunun en önemli nedeni, seçilen ülke gruplarının benzer ekonomik yapılara sahip olmasının tercih nedeni olmasıdır. Bu noktada ya tek bir ülke ya da aynı yapısal özelliklere sahip ülkeler birlikte incelenmiştir. Ancak bu çalışmada, farklı yapısal özelliklere sahip farklı entegrasyon grupları karşılaştırmalı biçimde incelenmiştir. Bu çalışmada seçilen entegrasyon örgütleri, NAFTA (ABD, Kanada ve Meksika), MERCOSUR (Arjantin, Brezilya, Paraguay, Uruguay ve Venezüella), AB15 (Fransa, Almanya, İtalya, Belçika, Hollanda, Lüksemburg, İngiltere, İrlanda, Danimarka, Yunanistan, İspanya, Portekiz, Avusturya, Finlandiya, İsveç) ve seçilmiş OECD (Avusturalya, Çekya, Kore, İsrail, İzlanda, Japonya, Kolombiya, Lüksemburg, Macaristan, Yeni Zelanda, Norveç ve Polonya) ülkeleridir. Çalışmada 1960-2019 dönemi için yıllık veriler ele alınmıştır. Veriler 'bruegel.org' adresinden elde edilmiştir. 


\subsection{Kesirli (Fraksiyonel) Frekanslı Fourier ADF Testi}

Literatüre bakıldığında geleneksel nitelikteki birim kök testleri, yapısal kırılmaları dikkate almamaktadır. Bununla birlikte, yapısal kırılmaları mutlaka önceden bilmek gerekliliğine vurgu yapmaktadır. Bu noktada Enders ve Lee (2012) yapısal kırılmaları önceden tahmin etmenin mümkün olmadığını savunmaktadır. Fourier fonksiyonlu birim kök analizi, yapısal kırılmaların önceden bilinmese bile, etkili analiz yapmaya olanak tanımaktadır (İltaş \& Demirgüneş, 2020: 979).

Dickey-Fuller testinde $\alpha(\mathrm{t})$ tarafindan deterministik terimin zamana bağlı bir fonksiyonu, şu şekilde gösterilmektedir (Enders \& Lee, 2012: 196-197):

$$
\mathrm{y}_{t}=\alpha(t)+\rho y_{t-1}+\gamma t+\varepsilon_{t}
$$

Yukaridaki fonksiyonda yer alan $\alpha(t)$ t'nin deterministik bir fonksiyonudur. Burada $\alpha(t)$ yanlış tanımlandıysa, test sorunlu olmaktadır. $\alpha(t)$ 'nin bilinmeyen işlevsel biçiminin bir yaklaşımı olarak, Fourier açılımı şu şekilde yazılabilir:

$$
\alpha(t)=\alpha_{0}+\sum_{k=1}^{n} \alpha_{k} \sin \left(\frac{2 \pi k t}{T}\right)+\sum_{k=1}^{n} \beta_{k} \cos \left(\frac{2 \pi k t}{T}\right) ; n \leq T / 2
$$

Burada $\mathrm{n}$, yaklaşımda yer alan frekansların sayısını, $\mathrm{t}$ trend terimi, $\mathrm{k}$ belirli bir frekansı temsil etmektedir. $\mathrm{T}$ ise, gözlemlerin sayısını ifade etmektedir. 5):

Çalışmada aşağıdaki modelin tahmini yapılmıştır (Bozoklu, Yılancı \& Görüş, 2020:

$$
\Delta y_{t}=\delta_{0}+\delta_{1} \sin \left(\frac{2 \pi k t}{T}\right)+\delta_{2} \cos \left(\frac{2 \pi k t}{T}\right)+\delta_{3} y_{t-1}+\sum_{i=1}^{p} \alpha_{i} \Delta y_{t-1}+v_{t}+e_{t}
$$

Yukarıda yer alan eşitlikte, $\mathrm{t}$ trend terimi, T gözlem sayısını, $\pi$ 3,1416, p optimal gecikme uzunluğunu ve $\mathrm{k}$ frekansını ifade etmektedir. Optimal lag uzunluğunu belirlemek için Akaike bilgi kriteri kullanılmıştır. Omay (2015) çalışmasında k'nın 0 ile 2 arasında olmasına izin verilirken Bozoklu, Yılancı \& Görüş (2020) çalışmalarında, bu değerin 0 ile 5 arasında olmasına izin verilmiştir.

Trigonometrik terimlerin anlamlılığ şu hipotezlerle sınanmaktadır:

$\mathrm{H}_{0}=$ Trigonometrik terimler anlamsız

$\mathrm{H}_{1}=$ Trigonometrik terimler anlaml

Trigonometrik terimlerin anlamsız çıktığı durumlarda, geleneksel ADF testi daha sağlıklı sonuçlar vermektedir.

Çalışmada kullanılan modelde hipotezler şu şekilde kurulmaktadır:

$\mathrm{H}_{0}=$ Seriler birim köklüdür. 
Ergün-Tatar, H. (2021), "Seçilmiş Entegrasyon Örgütlerinde Satın Alma Gücü Paritesi Teorisinin Geçerliliğinin Fourier Fonksiyonu Kullanarak Fraksiyonel Birim Kökleriyle Test Edilmesi”, Sosyoekonomi, 29(49), 373-388.

$\mathrm{H}_{1}=$ Seriler Durağandır.

Çalışmada kullanılan testin en önemli özelliği, serilerdeki kırılmaların sayısını, yerlerini ve formunu önceden bilme ihtiyacını ortadan kaldırmaktadır. Bununla birlikte değişimlerin kalıcı mı yoksa geçici mi olduğunun analiz edilmesine olanak tanımaktadır (Christopoulos \& Leon-Ledesma, 2011). Ayrıca bu testin en önemli özelliği, geçici şokların geçici etkileri olacağını ifade eden durağanlık sınamalarının eksikliklerini ortaya koymasıdır. Çünkü geçici şokların bile doğası gereği kalıcı politikalar gerektiren kalıcı etkileri söz konusu olmaktadır (Bozoklu, Yılancı \& Görüş, 2020). Çalışmada 0 ile 5 arasında frekansın 0.1 artışlarla artmasına izin verilmektedir. Bunun en önemli nedeni, aşırı filtrelemeyi ve problemleri sınırlama olasılığıdır (Omay, 2015).

Satın alma gücü paritesi teorisinin geçerliliğinin analizi için kullanılan Kesirli Frekanslı Fourier ADF Testi, dört farklı entegrasyon örgütü için hesaplanmıştır. Buna göre, Tablo 2'de NAFTA için test sonuçlarına yer verilmiştir. Serilerdeki durağanlık, FADF test istatistiğine göre sınanmıştır. Birim kök incelemesine geçmeden önce, trigonometrik terimlerin anlamlılığı sınanmıştır. Buna göre Meksika hariç tüm ülkelerde trigonometrik terimler anlamsızdır. Meksika'da trigonometrik terimlerin birlikte anlamlılığ 1 tespit edildikten sonra, durağanlık analiz sonuçları incelenmiştir. Buna göre, Meksika'da değişken durağandır. Diğger bir ifadeyle, satın alma gücü paritesi geçerlidir.

Tablo: 2

NAFTA için Kesirli Frekanslı Fourier ADF Test Sonuçları

\begin{tabular}{|c|c|c|c|c|c|c|c|c|}
\hline & Frekans & Min.KKT & F test İstatistiği & Uygun Gecikme & FADF Test İstatistiği & $\% 1$ & $\% 5$ & $\% 10$ \\
\hline ABD & 0.10 & 1281.710 & 3.195 & 11 & -4.106 & -4.490 & -3.882 & -3.582 \\
\hline KANADA & 5.00 & 870.626 & 1.165 & 1 & -2.616 & -3.549 & -2.923 & -2.587 \\
\hline MEKSİKA & 5.00 & 4116.325 & $7.713 * *$ & 1 & $-5.792 *$ & -3.549 & -2.923 & -2.587 \\
\hline
\end{tabular}

Tablo: 3

MERCOSUR için Kesirli Frekanslı Fourier ADF Test Sonuçları

\begin{tabular}{|l|c|c|c|c|c|c|c|c|}
\hline & Frekans & Min.KKT & F test İstatistiği & Uygun Gecikme & FADF Test İstatistiği & $\% 1$ & $\% 5$ & $\% 10$ \\
\hline ARJANTIN & 0.10 & 81979.95 & 3.098 & 1 & -3.809 & -4.490 & -3.882 & -3.582 \\
\hline BREZİLY & 2.90 & 5974.538 & 2.341 & 1 & -4.075 & -3.750 & -3.076 & -2.724 \\
\hline PARAGUAY & 3.30 & 16860.26 & 4.837 & 3 & -3.785 & -3.693 & -3.024 & -2.683 \\
\hline URUGUAY & 0.10 & 7913.612 & 5.314 & 1 & -3.204 & -4.490 & -3.882 & -3.582 \\
\hline VENEZUELA & 0.10 & 31602495 & 6.594 & 6 & 0.832 & -4.490 & -3.882 & -3.582 \\
\hline
\end{tabular}

Not: ***, **, * sirasıyla \%1, \%5 ve \%10 anlamlılık düzeylerinde anlamll olduğunu göstermektedir. Trigonometrik terimlerin anlamlılı̆̆ını sınamak için tablo değeri olarak Enders \& Lee (2012) çalışmasından yararlanılmıştır. Sabitli model ait FADF Tablo değerleri için, Bozoklu, Yılancı \& Görüş (2020) çalışmasından yararlanılmıştır.

Tablo 3'te MERCOSUR için Kesirli Frekanslı Fourier ADF test sonuçları yer almaktadır. Buna göre, Venezuela ülkesi hariç tüm ülkelerde trigonometrik terimler anlamsızdır. Dolayısıyla bu ülkelerde geleneksel ADF sonucuna bakmak gerekir. Venezuela'da ise trigonometrik terimler anlamlı olmasına rağmen, satın alma gücü paritesi geçerli değildir. 
Ergün-Tatar, H. (2021), "Seçilmiş Entegrasyon Örgütlerinde Satın Alma Gücü Paritesi Teorisinin Geçerliliğinin Fourier Fonksiyonu Kullanarak Fraksiyonel Birim Kökleriyle Test Edilmesi”, Sosyoekonomi, 29(49), 373-388.

Tablo 4'te AB15 için Kesirli Frekanslı Fourier ADF test sonuçları yer almaktadır. Buna göre; Almanya, İtalya, İrlanda, Yunanistan ve İsveç'te trigonometrik terimlerin birlikte anlamlı olduğu tespit edilmiştir. İrlanda hariç tüm ülkelerde satın alma gücü paritesinin geçerli olduğu söylenebilir. İrlanda'da ise trigonometrik terimler anlamlı olmasına rağmen, satın alma gücü paritesi geçerli değildir. Trigonometrik terimleri anlamsız olan ülkeler için geleneksel ADF sonucuna bakmak gerekir.

Tablo: 4

AB15 için Kesirli Frekanslı Fourier ADF Test Sonuçları

\begin{tabular}{|c|c|c|c|c|c|c|c|c|}
\hline & Frekans & Min.KKT & F test İstatistiği & Uygun Gecikme & FADF Test İstatistiği & $\% 1$ & $\% 5$ & $\% 10$ \\
\hline FRANSA & 4.00 & 496.074 & 3.905 & 1 & -3.442 & -3.627 & -2.965 & -2.634 \\
\hline ALMANYA & 3.60 & 587.450 & $7.478^{*}$ & 2 & $-3.264 * *$ & -3.688 & -3.009 & -2.665 \\
\hline İTALYA & 2.80 & 615.382 & $8.224 * *$ & 1 & $-3.521^{* *}$ & -3.768 & -3.084 & -2.736 \\
\hline BELÇİKA & 3.80 & 496.767 & 2.992 & 1 & -3.415 & -3.637 & -2.981 & -2.643 \\
\hline HOLLANDA & 3.80 & 496.693 & 5.024 & 2 & -3.274 & -3.637 & -2.981 & -2.643 \\
\hline LÜKSEMBURG & 3.70 & 295.081 & 1.902 & 1 & -1.948 & -3.666 & -2.992 & -2.643 \\
\hline İNGÍLTERE & 3.00 & 1199.587 & 4.082 & 1 & -4.537 & -3.732 & -3.056 & -2.712 \\
\hline İRLANDA & 2.70 & 575.835 & $6.500 *$ & 3 & -1.728 & -3.800 & -3.097 & -2.745 \\
\hline DANIMARKA & 3.80 & 379.350 & 5.179 & 2 & -2.617 & -3.637 & -2.981 & -2.643 \\
\hline YUNANISTAN & 1.10 & 393.277 & $11.382 * * *$ & 5 & $-4.449 * * *$ & -4.355 & -3.745 & -3.416 \\
\hline İSPANYA & 4.20 & 625.452 & 4.025 & 1 & -2.235 & -3.620 & -2.963 & -2.627 \\
\hline PORTEKİZ & 3.50 & 426.255 & 3.474 & 2 & -1.026 & -3.689 & -3.009 & -2.664 \\
\hline AVUSTURYA & 3.90 & 251.504 & 3.347 & 1 & -1.872 & -3.621 & -2.964 & -2.640 \\
\hline FINLANDİYA & 5.00 & 1163.350 & 2.233 & 2 & -2.450 & -3.549 & -2.923 & -2.587 \\
\hline İSVEÇ & 0.60 & 1205.441 & $8.144 * *$ & 1 & $-4.016^{* *}$ & -4.551 & -3.942 & -3.639 \\
\hline
\end{tabular}

Not: ***, **, * strasılla \%1, \%5 ve \%10 anlamlılık düzeylerinde anlaml olduğunu göstermektedir. Trigonometrik terimlerin anlamlılı̆̆ını sınamak için tablo değeri olarak Enders \& Lee (2012) çalışmasından yararlanılmıştır. Sabitli model ait FADF Tablo değerleri için, Bozoklu, Yılancı \& Görüş (2020) çalışmasından yararlanılmıştır.

Tablo: 5

Seçilmiş OECD Ülkeleri için Kesirli Frekanslı Fourier ADF Test Sonuçları

\begin{tabular}{|c|c|c|c|c|c|c|c|c|}
\hline & Frekans & Min.KKT & F test İstatistiği & Uygun Gecikme & FADF Test İstatistiği & $\% 1$ & $\% 5$ & $\% 10$ \\
\hline AVUSTURALYA & 1.5 & 1328.464 & $8.643^{* *}$ & 1 & $-4.675^{* * *}$ & -4.162 & -3.477 & -3.129 \\
\hline CCEK CUMHURIYYETİ & 1.2 & 2978.183 & $11.282^{* * * * *}$ & 7 & $-4.526^{* * * *}$ & -4.326 & -3.682 & -3.345 \\
\hline KORE & 3.9 & 3561.196 & 5.764 & 5 & -2.048 & -3.621 & -2.964 & -2.640 \\
\hline İSRAİL & 2.3 & 5347.428 & 5.160 & 5 & -4.439 & -3.899 & -3.200 & -2.838 \\
\hline İZLANDA & 4.6 & 2962.142 & 1.519 & 9 & -1.359 & -3.607 & -2.948 & -2.617 \\
\hline JAPONYA & 0.9 & 4400.719 & $10.368^{* * * *}$ & 1 & $-4.974 * * * *$ & -4.460 & -3.865 & -3.551 \\
\hline KOLOMBİYA & 0.9 & 3321.547 & $7.832 * *$ & 10 & $-4.481 * * *$ & -4.460 & -3.865 & -3.551 \\
\hline LÜKSEMBURG & 3.7 & 295.081 & 1.902 & 1 & -1.948 & -3.666 & -2.992 & -2.647 \\
\hline MACARISTAN & 0.9 & 505.360 & $7.919 * *$ & 5 & $-3.557^{*}$ & -4.460 & -3.865 & -3.551 \\
\hline YENİ ZELANDA & 0.6 & 1376.122 & $13.599^{* * * *}$ & 3 & $-5.446 * * *$ & -4.551 & -3.942 & -3.639 \\
\hline NORVEC & 2.2 & 346.090 & 2.870 & 1 & -2.966 & -3.933 & -3.218 & -2.861 \\
\hline POLONYA & 1.1 & 2743.427 & $13.027^{* * * * *}$ & 2 & $-5.187 * * *$ & -4.355 & -3.745 & -3.416 \\
\hline
\end{tabular}

Tablo 5’te Seçilmiş OECD ülkeleri için Kesirli Frekanslı Fourier ADF test sonuçları yer almaktadır. Buna göre; Avusturalya, Çekya, Japonya, Kolombiya, Macaristan, Yeni Zelanda ve Polonya'da trigonometrik terimlerin birlikte anlamlı olduğu tespit edilmiştir. FADF test sonucuna göre ise, reel döviz kuru değişkenin seviye itibariyle durağan olduğu sonucuna ulaşılmıştır. Diğer bir deyişle, söz konusu ülkelerde satın alma gücü hipotezinin geçerli olduğu söylenilebilir. Ayrıca, trigonometrik terimleri anlamsız olan ülkeler için geleneksel ADF sonucuna bakmak gerekir. 


\subsection{Geleneksel ADF Birim Kök Testi}

Aşağıdaki NAFTA, MERCOSUR, AB15 ve seçilmiş OECD ülkelerine ait, geleneksel ADF birim kök testleri gösterilmektedir. Buna göre, öncelikle Tablo 6'da NAFTA için geleneksel ADF test sonuçları gösterilmektedir. Buna göre, ABD ve Meksika'da değişken durağandır. Diğer bir deyişle satın alma gücü paritesi geçerlidir. Kanada'da ise değişkenin birim köklü olduğu görülmektedir. Dolayısıyla bu ülkede satın alma gücü paritesi geçerli değildir.

\section{Tablo: 6}

\section{NAFTA için Geleneksel ADF Birim Kök Testi Sonuçları (Sabitli Model)}

\begin{tabular}{|l|c|c|}
\hline Ülkeler & Test İstatistik Değeri & Olasilık \\
\hline ABD & -3.220 & $(0.023)^{* * *}$ \\
\hline KANADA & -2.363 & $(0.156)$ \\
\hline MEKSİKA & -3.956 & $(0.003)^{* * *}$ \\
\hline
\end{tabular}

Not: ***, **, * sirasıyla \%1, \%5 ve \%10 anlamlılık düzeylerinde anlaml olduğunu göstermektedir. Katsayı değerlerin altında yer alan parantezler, standart hatalarl göstermektedir.

\section{Tablo: 7}

\section{MERCOSUR için Geleneksel ADF Birim Kök Testi Sonuçları (Sabitli Model)}

\begin{tabular}{|l|c|c|}
\hline \multicolumn{1}{|c|}{ Ülkeler } & Test İstatistik Değeri & Olasilık \\
\hline ARJANTIN & -2.677 & $(0.084)^{*}$ \\
\hline BREZİLYA & -2.733 & $(0.074)^{*}$ \\
\hline PARAGUAY & -1.677 & $(0.437)$ \\
\hline URUGUAY & -0.962 & $(0.760)$ \\
\hline VENEZUELA & -6.355 & $(0.000)^{* * *}$ \\
\hline
\end{tabular}

Not: ***, **, * strasıyla \%1, \%5 ve \%10 anlamlılı düzeylerinde anlaml olduğunu göstermektedir. Katsayl değerlerin altında yer alan parantezler, standart hataları göstermektedir.

Tablo 7'de, MERCOSUR için Geleneksel birim kök test sonuçları yer almaktadır. Buna göre, Arjantin, Brezilya ve Venezuela'da değişkenin seviye itibariyle durağan olduğu ve satın alma gücü paritesinin geçerli olduğu görülmektedir. Buna karşın Paraguay ve Uruguay'da satın alma gücü paritesi geçerli değildir.

\section{Tablo: 8}

\section{AB15 için Geleneksel ADF Birim Kök Testi Sonuçları (Sabitli Model)}

\begin{tabular}{|c|c|c|}
\hline Ülkeler & Test İstatistik Değeri & Olasılık \\
\hline FRANSA & -2.990 & $(0.041)^{* * *}$ \\
\hline ALMANYA & -3.105 & $(0.031)^{* *}$ \\
\hline ITALYA & -2.227 & $(0.199)$ \\
\hline BELÇİKA & -3.532 & $(0.010)^{* * *}$ \\
\hline HOLLANDA & -2.582 & $(0.102)^{* * *}$ \\
\hline LÜKSEMBURG & -2.609 & $(0.096)^{*}$ \\
\hline İNGİLTERE & -3.687 & $(0.006)^{* * * *}$ \\
\hline İRLANDA & -2.030 & $(0.273)$ \\
\hline DANIMARKA & -2.176 & $(0.216)$ \\
\hline YUNANISTAN & -1.394 & $(0.578)$ \\
\hline İSPANYA & -1.923 & $(0.319)$ \\
\hline PORTEKİZ & -1.420 & $(0.566)$ \\
\hline AVUSTURYA & -1.539 & $(0.507)$ \\
\hline FINLANDİYA & -2.680 & $(0.083)^{*}$ \\
\hline İSVEÇ & -0.514 & $(0.880)$ \\
\hline
\end{tabular}


Tablo 8'de, AB15 için Geleneksel birim kök test sonuçları yer almaktadır. Buna göre, Fransa, Almanya, Belçika, Hollanda, Lüksemburg, İngiltere ve Finlandiya'da değişkenin seviye itibariyle durağan olduğu ve satın alma gücü paritesinin geçerli olduğu görülmektedir. Buna karşın, Belçika, İrlanda, Danimarka, Yunanistan, İspanya, Portekiz, Avusturya, Finlandiya ve İsveç’te satın alma gücü paritesinin geçerli olmadığ görülmektedir.

Tablo: 9

\section{Seçilmiş OECD için Geleneksel ADF Birim Kök Testi Sonuçları (Sabitli Model)}

\begin{tabular}{|c|c|c|}
\hline Ülkeler & Test İstatistik Değeri & Olasılık \\
\hline AVUSTURALYA & -2.447 & $(0.133)$ \\
\hline ÇEKYA & -1.369 & $(0.590)$ \\
\hline KORE & -2.461 & $(0.130)$ \\
\hline İSRAİL & -4.376 & $(0.000)^{* * * *}$ \\
\hline İZLANDA & -2.582 & $(0.102)$ \\
\hline JAPONYA & -2.017 & $(0.278)$ \\
\hline KOLOMBİYA & -3.505 & $(0.011)^{* * *}$ \\
\hline LÜKSEMBURG & -2.609 & $(0.096)^{*}$ \\
\hline MACARİSTAN & -1.066 & $(0.722)$ \\
\hline YENİ ZELANDA & 0.293 & $(0.975)$ \\
\hline NORVEÇ & -2.426 & $(0.139)$ \\
\hline POLONYA & -1.602 & $(0.475)$ \\
\hline
\end{tabular}

Tablo 9'da seçilmiş OECD ülkeleri için Geleneksel birim kök test sonuçları yer almaktadır. Buna göre, İsrail, Kolombiya ve Lüksemburg'da satın alma gücü paritesinin geçerli olduğu sonucuna ulaşılmıştır. Avusturalya, Çek Cumhuriyeti, Kore, İzlanda, Japonya, Macaristan, Yeni Zelanda, Norveç ve Polonya'da satın alma gücü paritesinin geçerli olmadığı görülmektedir.

\section{Sonuç}

Satın alma gücü hipotezini analiz etmek için, 1960-2019 dönemi verileri incelenmiştir. Çalışma kapsamında seçilen entegrasyon örgütleri, NAFTA (ABD, Kanada ve Meksika), MERCOSUR (Arjantin, Brezilya, Paraguay, Uruguay ve Venezüella), AB15 (Fransa, Almanya, İtalya, Belçika, Hollanda, Lüksemburg, İngiltere, İrlanda, Danimarka, Yunanistan, İspanya, Portekiz, Avusturya, Finlandiya, İsveç) ve seçilmiş OECD (Avusturalya, Çek Cumhuriyeti, Kore, İsrail, İzlanda, Japonya, Kolombiya, Lüksemburg, Macaristan, Yeni Zelanda, Norveç ve Polonya) ülkeleridir.

Satın alma gücü paritesi teorisinin geçerliliğinin analizi için Kesirli Frekanslı Fourier ADF Testi ve geleneksel ADF testleri için hesaplamalar yapılmıştır. Yapılan hesaplamalarda trigonometrik terimleri anlamsız olan ülkelerde, Kesirli Frekanslı Fourier ADF Testi yerine geleneksel ADF uygulanmıştır. Öncelikle NAFTA'da, Meksika hariç tüm ülkelerde trigonometrik terimlerin anlamsız olduğu tespit edilmiştir. Meksika'da trigonometrik terimlerin birlikte anlamlılığı tespit edildikten sonra, durağanlık analiz sonuçları incelenmiştir. Buna göre, Meksika'da değişkenin durağan olduğu saptanmıştır. Yani bu ülkede satın alma gücü paritesi geçerlidir. Ülkeye ait frekans değeri 5'tir. ABD ve Kanada 
Ergün-Tatar, H. (2021), "Seçilmiş Entegrasyon Örgütlerinde Satın Alma Gücü Paritesi Teorisinin Geçerliliğinin

Fourier Fonksiyonu Kullanarak Fraksiyonel Birim Kökleriyle Test Edilmesi”, Sosyoekonomi, 29(49), 373-388.

için geleneksel ADF sonuçlarına göre, ABD'de SGP geçerli iken Kanada'da SGP geçerli değildir. NAFTA için panelin tamamı birlikte değerlendirildiğinde, SGP geçerli olduğu sonucuna ulaşılmıştır.

MERCOSUR'da Kesirli Frekanslı Fourier ADF Testi sonucuna göre, Venezuela ülkesi hariç tüm ülkelerde trigonometrik terimler anlamsızdır. Venezuela'da frekans değeri 0.10 olarak tespit edilmiştir. Analiz sonuçlarına göre ise, SGP bu ülkede geçerli değildir. Diğer ülkeler için trigonometrik terimler anlamsız olduğu için geleneksel ADF sonucuna bakmak gerekir. Buna göre, Arjantin ve Brezilya'da SGP'nin geçerli olduğu tespit edilmiştir. Paraguay ve Uruguay'da ise, SGP'nin geçerli olmadığı belirlenmiştir. MERCOSUR için panelin tamamı birlikte değerlendirildiğinde, SGP geçerli olmadığ sonucuna ulaşılmıştır.

AB15 ülkelerinde Kesirli Frekanslı Fourier ADF Testi sonucuna göre, Almanya, İtalya, İrlanda, Yunanistan ve İsveç’te trigonometrik terimlerin birlikte anlamlı olduğu tespit edilmiş̧ir. İkinci aşama olarak bakılan durağanlık sınamasına göre, İrlanda hariç tüm ülkelerde satın alma gücü paritesinin geçerli olduğu tespit edilmiştir. Söz konusu ülkelerde kesirli frekans değerleri sırasılyla şu şekildedir: $3.60,2.80,2.70,1.10$ ve 0.60 . İlanda'da ise trigonometrik terimler anlamlı olmasına rağmen, satın alma gücü paritesi geçerli değildir. Diğer ülkeler için geleneksel ADF sonucu dikkate alınmalıdır. Buna göre, Fransa, Belçika, Hollanda, Lüksemburg, İngiltere ve Finlandiya'da SGP'nin geçerli olduğu tespit edilmiştir. Danimarka, İspanya, Portekiz ve Avusturya'da ise SGP'nin geçerli olmadığı tespit edilmiştir. AB15 için panelin tamamı birlikte değerlendirildiğinde, SGP geçerli olduğu sonucuna ulaşılmıştır.

Seçilmiş OECD ülkelerinde Kesirli Frekanslı Fourier ADF Testi sonucuna göre, Avusturalya, Çek Cumhuriyeti, Japonya, Kolombiya, Macaristan, Yeni Zelanda ve Polonya' da trigonometrik terimlerin birlikte anlamlı olduğu tespit edilmiştir. İkinci aşama olarak bakılan durağanlık sınamasına göre, trigonometrik terimleri anlamlı olan tüm ülkelerde SGP'nin geçerli olduğu tespit edilmiştir. Söz konusu ülkelerde kesirli frekans değerleri sırasıyla şu şekildedir: $1.5,1.2,0.9,0.9,0.9,0.6$ ve 1.1. Diğer ülkeler için yapılan geleneksel ADF testi sonuçları şu şekildedir: İsrail ve Lüksemburg'da SDP geçerli iken, diğer ülkelerde SGP geçerli değildir. Seçilmiş OECD ülkeleri için panelin tamamı birlikte değerlendirildiğinde, SGP geçerli olduğu sonucuna ulaşılmıştır.

Satın alma gücü hipotezinin geçerliliğini sınamak için, zaman aralığının geniş olması gerekmektedir. Çalışmada zaman aralığı geniş olmakla birlikte, Fourier işleviyle yapısal kırılmaları modellemeye izin veren fraksiyonel birim kök bulgularının, diğer birim kök test yöntemlerine göre, daha anlamlı ve güvenilir sonuç verdiği görülmektedir. Bu durumun, özellikle politika yapıcıların doğru yönlendirilmesi noktasında, ciddi katkılar sağlayacağı düşünülmektedir. Konunun öneminden hareketle bu çalışmada, reel döviz kuru sınamasının yumuşak geçişli yapısal değişimlerin dikkate alıp incelenmesi açısından diğer testlere göre daha tutarlidır. 
Ergün-Tatar, H. (2021), "Seçilmiş Entegrasyon Örgütlerinde Satın Alma Gücü Paritesi Teorisinin Geçerliliğinin Fourier Fonksiyonu Kullanarak Fraksiyonel Birim Kökleriyle Test Edilmesi”, Sosyoekonomi, 29(49), 373-388.

Çalışmada kesirli frekanslar yapısal değişikliğin geçici olmayan özellik gösterdiğini ifade etmektedir. Politika oluşturulmasında bu durum mutlaka dikkate alınmalıdır. Kesirli frekans yönteminin en önemli avantajı, geçici şokların geçici etkilere sahip olacağını kabul eden durağanlık analizlerinden farklı olmasıdır. Çünkü geçici şokların bile kalıcı politika gerektiren, kalıcı etkileri söz konusu olabilir (Bozoklu, Yılancı \& Görüş, 2020). Satın alma gücü paritesinin analizi politik konular ve uluslararası parasal ekonomi açısından son derece önemlidir. Hipotezin testi döviz kuru politikası ve döviz kuru paritenin ayarlanmasıyla doğrudan ilişkilidir. Bu noktada yapısal uyum politikaları, ekonomik reform programları ve finansal istikrar planları açısından hipotezin geçerliliği önemli bir göstergedir (Destek \& Okumuş, 2016: 74). Reel döviz kurunun birim köklü çıkmaması, ülkede finansal istikrarının sağlaması noktasında önem teşkil etmektedir. SGP'nin geçerli olmadığı ülkelerde, istikrarlı döviz kuru politikalarından bahsetmek mümkün değildir. Benzer şekilde söz konusu ülkelerde, fiyat farklılıklarını yok edecek bir nominal kurun gerçekleşmediği söylenebilir. Döviz kurunun durağan çıkmadığı ülke veya ülke gruplarında, döviz kuru istikrarı hedef olarak belirlenmelidir. Bu noktada, kur istikrarını sağlayan faiz politikası uygulanmalıdır. Ancak bu sayede, izlenen politikalar ekonomi üzerinde olumlu etki yaratmakta ve döviz kuru değişimleri istikrarlı bir hale gelmektedir.

\section{Kaynaklar}

Acaravc1, A. \& I. Öztürk (2010), “Testing Purchasing Power Parity in Transition Countries: Evidence From Structural Breaks", Amfiteatru Economic Journal, 12(27), 190-198.

Ağayev, S. (2013), "Satın Alma Gücü Paritesi Hipotezinin Kazakistan için Geçerliliğ̈i", $\langle$ http://avekon.org/papers/594.pdf>, 21.09.2020.

Akçay, A.Ö. \& F. Erataş (2015), "Satın Alma Gücü Paritesi Teorisinin Geçerliliği: G7 Örneği”, <https://dergipark.org.tr/en/download/article-file/89274>, 20.09.2020.

Alba, J.D. \& D.H. Papell (2007), "Purchasing Power Parity and Country Characteristics: Evidence From Panel Data Tests", Journal of Development Economics, 83(1), 240-251.

Al-Gasaymeh, A. \& J. Kasem (2015), "Strong and Weak Form of Purchasing Power Parity: The Case of Jordan and Its Major Trading Partners", Journal of International Business and Economics, 3(1), 93-108.

Altıner, A. \& E. Bozkurt (2018), "The Validity of Purchasing Power Parity Hypothesis in E-7 Countries: Panel Data Analysis", Business and Economics Research Journal, 9(4), 735747.

Atasoy, A.B. (2016), "Satınalma Gücü Paritesi, Kırılgan Beşli Ülkeleri’nde Geçerli Midir?", Uluslararası Yönetim İktisat ve İșletme Dergisi, 30, 237-246.

Aydın, M. (2018), "Examination of The Validity of Purchasing Power Parity (PPP) with Fractured Fourier Unit Root Tests: The Case of Fragile Five Countries", Journal of Applied Research in Finance and Economics, 3(4), 18-28.

Bilgin, C. (2018), "Uluslararası Ticarette Satın Alma Gücü Paritesinin Geçerliliği Sorunu: Türkiye için Zaman Serisi Analizi", <https://mpra.ub.unimuenchen.de/87630/2/MPRA_paper_87630.pdf>, 10.09.2020.

Bozoklu, S. \& V. Yllancı \& M.S. Görüş (2020), "Persistence in Per Capita Energy Consumption: A Fractional Integration Approach with A Fourier Function”, Energy Economics, 91, 1-12. 
Bruegel (2020), <https://www.bruegel.org/publications/datasets/real-effective-exchange-rates-for178-countries-a-new-database/>, 10.10.2020.

Büberkökü, Ö. (2014), "Yükselen Piyasa Ekonomilerinde Uluslararası Satın Alma Gücü Paritesi: Panel Koentegrasyon Testlerinden Kanitlar", Journal of BRSA Banking \& Financial Markets, 8(1), 117-139.

Calderón, C. \& R. Duncan (2003), "Purchasing Power Parity in An Emerging Market Economy: A Long-Span Study for Chile", Documentos de Trabajo (Banco Central de Chile), 215, 143.

Chang, H.L. \& D.C. Liu \& C.W. Su (2012), "Purchasing Power Parity with Flexible Fourier Stationary Test for Central and Eastern European Countries", Applied Economics, 44(32), 4249-4256.

Chang, T. \& K.C. Lee (2011), "Purchasing Power Parity in East Asian Countries: Flexible Fourier Stationary Test", Asian Journal of Business and Management Sciences, 1(5), 38-46.

Christopoulos, D.K. \& M.A. Leon-Ledesma (2011), "International Output Convergence, Breaks, And Asymmetric Adjustment”, Studies in Nonlinear Dynamics \& Econometrics, 15(3), $1-31$.

Coşkun, N. (2020), “Mutlak Satın Alma Gücü Paritesi Hipotezi: Kırılgan Beşli Örneği”, Bulletin of Economic Theory and Analysis, 5(1), 41-55.

Culver, S. \& D. Papell (1999), "Long-Run Purchasing Power Parity with Short-Run Data: Evidence with a Null Hypothesis of Stationarity", Journal of International Money and Finance, 18, 751-768.

Çil, N. \& B.Y. Tıraşoğlu (2018), "Validity of Purchasing Power Parity in Fragile Five Countries: The Bayesyen Unit Root Analysis”, Sosyal Bilimler Araştırma Dergisi, 7(2), 82-90.

Dal Bianco, M.J. (2008), “Argentinean Real Exchange Rate 1900-2006: Testing Purchasing Power Parity Theory", Estudios de Economía, 35(1), 33-64.

Destek, M.A. \& İ. Okumuş (2016), "Satın Alma Gücü Paritesi Hipotezi Geçerliliğinin Fourier Birim Kök Testleri ile İncelenmesi: OECD Ülkeleri Örneği”, Gaziantep Üniversitesi Sosyal Bilimler Dergisi, 15(1), 73-87.

Doğanlar, M. (2006), "Long-Run Validity of Purchasing Power Parity and Cointegration Analysis for Central Asian Countries", Applied Economics Letter, 13, 457-461.

Enders, W. \& J. Lee (2012), “The Flexible Fourier Form and Dickey-Fuller Type Unit Root Tests", Economics Letters, 117(1), 196-199.

Freixo, C.S. \& F.H. Barbosa (2004), "Purchasing Power Parity: A Non-Linear Reversion Model for Brazil”, Revista Economia, 5, 75-115.

Güriş, B. \& M. Tiraşoğlu (2018), "The Validity of Purchasing Power Parity in BRICS Countries", Prague Economic Papers, 27(4), 1-10.

He, H. \& M.C. Chou \& T. Chang (2014), "Purchasing Power Parity for 15 Latin American Countries: Panel SURKSS Test with A Fourier Function”, Economic Modelling, 36, 3743.

Ismail, H. (2011), "Evidence of Purchasing Power Parity From Asean Data”, Journal of Quality Measurement and Analysis JQMA, 7(2), 15-22. 
Ergün-Tatar, H. (2021), "Seçilmiş Entegrasyon Örgütlerinde Satın Alma Gücü Paritesi Teorisinin Geçerliliğinin Fourier Fonksiyonu Kullanarak Fraksiyonel Birim Kökleriyle Test Edilmesi”, Sosyoekonomi, 29(49), 373-388.

İltaş, Y. \& K. Demirgüneş (2020), “Döviz Kurunun Borsa İstanbul Sanayi Endeksi Üzerindeki Etkisi: Yapısal Kırılmaları Modellemede Farklı Yaklaşımlar Kullanan Eşbütünleşme Testlerinden Bulgular", Üçüncü Sektör Sosyal Ekonomi Dergisi, 55(2), 972-988.

Jiranyakul, K. \& B. Batavia (2012), "Does Purchasing Power Parity Hold in Thailand?", International Journal of Applied Economics and Econometrics, 17(3), 268-280.

Kalyoncu, H. \& F. Kula \& A. Aslan (2010), "The Validity of Purchasing Power Parity Hypothesis in Middle East And Northern Africa Countries", Romanian Journal of Economic Forecasting, 4(13), 125-131.

Kaya, H. \& İ. Çelik (2018), “Türkiye’de Satın Alma Gücü Paritesi Hipotezinin Geçerliliği: Uzun Hafiza Testlerinden Kanıtlar”, Mehmet Akif Ersoy Üniversitesi İkisadi ve İdari Bilimler Fakültesi Dergisi, 5(2), 351-365.

Korkmaz, T. \& İ.E. Çevik \& N.K. Çevik (2013), "Satın Alma Gücü Paritesinin Azerbaycan, Kazakistan ve Kırgızistan İçin Geçerliliği: Birim Kök ve Eşbütünleşme Analizi”, Bilig, 64, 259-284.

Koukouritakis, M. (2009), "Testing The Purchasing Power Parity: Evidence from The New EU Countries", Applied Economics Letters, 16(1), 39-44.

Kozul, I. (2013), "Cointegration analysis of purchasing power parity in Republic of Croatia", UTMS Journal of Economics, 4(3), 253-268.

Köktürk, O. \& M. Ural, (2019), "Fourier Birim Kök Testi ile Satın Alma Gücü Paritesinin Türkiye İçin Geçerliliğinin Analizi”, Business \& Management Studies: An International Journal, 7(2), 877-890.

Lothian, J. \& M.P. Taylor (1996), "Real Exchange Rate Behavior: The Recent Float from the Perspective of the Past Two Centuries", Journal of Political Economy, 104, 488-510.

Merza, E. (2017), “The Validity of The Purchasing Power Parity Hypothesis For Kuwait”, Modern Applied Science, 11(1), 188-194.

Mkenda, B.K. (2001), "An Empirical Test of Purchasing Power Parity in Selected African CountriesA Panel Data Approach", Department of Economics, Goteborg University, Working Papers in Economics, 39, 1-43.

Muscatelli, V.A. \& F. Spinelli (1999), "Purchasing Power Parity and Real Exchange Rates: Do Productivity Trends and Fiscal Policy Matter?", <https://www.gla.ac.uk/media/Media_219082_smxx.pdf>, 10.10.2020.

Nusair, S.A. (2003), "Testing The Validity of Purchasing Power Parity for Asian Countries During The Current Float", Journal of Economic Development, 28(2), 129-147.

Omay, T. (2015), "Fractional Frequency Flexible Fourier Form to Approximate Smooth Breaks in Unit Root Testing", Econ. Lett, 134, 123-126.

Öcal, O. (2013), "Purchasing Power Parity in The Case of Romania: Evidence From Structural Breaks”, International Journal of Economics And Financial Issues, 3(4), 973-976.

Papell, D.H. (1997), "Searching for Stationarity: Purchasing Power Parity under the Current Float", Journal of International Economics, 43, 313-32.

Rezazadeh, A. \& S. Mohammadpoor \& F. Fattahi (2018), "The Validity of Purchasing Power Parity Theory in Iran: Evidence from Markov-Switching Unit Root Test”, Quarterly Journal of Applied Theories of Economics, 5(2), 55-80. 
Rogoff, K. (1996), “The Purchasing Power Parity Puzzle”, Journal of Economic Literature, 34, 647667.

Si Mohammed, K. \& N. Chérif Touil \& S. Maliki (2015), An Empirical Test of Purchasing Power Parity of The Algerian Exchange Rate: Evidence from Panel Dynamic, <https://mpra.ub.uni-muenchen.de/75285/1/MPRA_paper_75285.pdf>, 20.11.2020.

Songur, D.Y. \& M. Songur (2018), "Revisiting Purchasing Power Parity for Eurasian Countries: A Fourier Approach", içinde: İ. Şiriner \& Z. Yardım-Kılıçkan, Institutions Development \& Economic Growth, IJOPEC Publication, 131-138.

Su, C.W. \& C. Tsangyao \& H.L. Chang (2011), "Purchasing Power Parity for Fifteen Latin American Countries: Stationary Test with A Fourier Function", International Review of Economics and Finance, 20, 839-845.

Su, C.W. \& Y.S. Liu \& M.N. Zhu \& K.C. Lee (2012), "Purchasing Power Parity in Major OPEC Countries: Flexible Fourier Stationary Test", Applied Economics Letters, 19(1), 19-24.

Suluk, S. \& K. Tanriseven (2018), "Purchasing Power Parity in The Euro Area: Evidence from Structural Break LM Test”, International Journal of Economics and Financial Issues, 8(2), 370-375.

Taylor, A.M. (2002), “A Century of Purchasing-Power Parity”, The Review of Economics and Statistics, 84(1), 139-150.

Vasconcelos, C.R.F. \& L.A.L Júnior (2016), "Validity of Purchasing Power Parity for Selected Latin American Countries: Linear and Non-Linear Unit Root Tests". EconomiA, 17(1), 114125.

Voinea, L.G. (2013), “The Purchasing Power Parity: Evidence from The Great Financial Crisis", Universidad Complutense, <https://www.ucm.es/data/cont/docs/518-2013-10-23Guinea13.pdf>, 23.11.2012.

Widodo, T. (2015), "Purchasing Power Parity and Productivity-Bias Hypothesis", Review of Economic and Business Studies, 8(2), 9-38.

Wu, J.L. \& S.Y. Cheng \& H. Hou (2011), "Further Evidence on Purchasing Power Parity and Country Characteristics", International Review of Economics \& Finance, 20(2), 257-266.

Yılanc1, V. \& Eriş, Z.A. (2013), "Purchasing Power Parity in African Countries: Further Evidence from Fourier Unit Root Tests Based on Linear and Nonlinear Models", South African Journal of Economics, 81(1), 20-34.

Y1lanc1, V. \& M. Aslan \& Ö. Özgür (2018), "Testing The Validity of PPP Theory for African Countries", Applied Economics Letters, 25(18), 1273-1277.

Ziad., A.-L. \& G. Abdallah (2018), "Testing the Validity of Purchasing Power Parity for The Jordanian Economy", International Journal of Academic Research in Economics and Management Sciences, 7(4), 192-200.

Zumaquero, A.M. \& R.P. Urrea (2002), "Purchasing Power Parity: Error Correction Models and Structural Breaks", Open Economies Review, 12, 5-26. 